\title{
DIVINE IDEALISM AS PHYSICALISM? REFLECTIONS ON THE STRUCTURAL DEFINITION OF PHYSICALISM
}

\author{
Jon W. Thompson
}

\begin{abstract}
Hempel's Dilemma remains at the center of the problem of defining physicalism. In brief, the dilemma asks whether physicalism should be defined by appeal to current or future physics. If defined by current physics, physicalism is almost certainly false. If defined by an ideal future physics, then physicalism has little determinable content. Montero and Papineau have innovatively suggested that the dilemma may be avoided by defining physicalism structurally. While their definition is one among many definitions, it is significant in that-if successful-it would break the impasse for defining physicalism. I argue, however, that the structural definition fails because it counts metaphysical frameworks (crucially, versions of divine idealism) as "physicalist" - an unwelcome result for physicalists. This paper thus furthers the debate on the definition of physicalism and sheds light on the relationship between physicalism and idealism.
\end{abstract}

\section{Hempel's Dilemma}

Physicalism is often defined as the view that all that exists is what physics studies; but many voices have raised concerns over such a definition. Indeed, the problem of defining physicalism has been with us for some time now. " "Hempel's Dilemma" puts the problem in exacting focus: when the physicalist claims that all that exists is physical, is she claiming that [A] All that exists is what is studied by current physics or that [B] All that exists is what is studied by some ideal, perhaps future, physics? ${ }^{2}$ If the physicalist intends [A], then physicalism is clearly false. After all, it would be difficult to find a physicist with the hubris to claim that her physics is the physics, that it will not advance - and likely advance substantially - away from positing its current postulates. On the other hand, if the physicalist intends [B], then physicalism becomes essentially a vacuous theory. After all, it is an open question what kinds of entities an ideal physics would disclose-thus the continuous project of physical investigation and dis-

${ }^{1}$ For a helpful overview of the history of the debate, see Ney, "Defining Physicalism."

2See Hempel, “Comments on Goodman's Ways of Worldmaking," 194-195. 
covery. To claim that physicalism amounts to nothing more than that "all that exists is what an ideal physics discloses or describes" seems to give up the game. The ideal theory may, after all, allow for the existence of entities that are (from the physicalist's perspective) rather metaphysically suspect (such as immaterial souls or ghosts). The physical theory which included such entities (and yet provided the best explanation for all the empirical data in the ideal theory) would still count as "physicalism" under [B]. But surely the physicalist wishes to make a more substantive claim than that. ${ }^{3}$

\section{The Structural Definition of Physicalism}

Montero and Papineau are alive to the problem of the definition of physicalism, and they have suggested that the dilemma can be answered. ${ }^{4}$ Their proposed method for defining physicalism seems to be to outline the structure of the envisioned theory: physicalism's structure consists in (1) the causal completeness of some realm (which they label generically " $\mathrm{Q}$ ") and (2) the reduction of mental and biological facts to "Q facts." By outlining the structure of physicalism, rather than appealing to either current or ideal physical theory, Hempel's Dilemma can be avoided. It is necessary to quote Montero and Papineau at length:

In truth, there are a number of alternative ways of defining "physical," all of which give rise to interesting doctrines arguably worth calling "physicalism." All that is needed is some way of identifying a category of facts (call them "Q") that satisfies the following requirements: (1) at first sight mental, biological, and similar categories do not seem to be $\mathrm{Q}$, but (2) mental, biological, and similar facts nevertheless do have effects among $Q$ facts, while at the same time (3) there is good reason to think that $Q$ is "causally complete": that is, that Q-effects always have fully Q-causes. As soon as we have a Q-category that satisfies these specifications, we can illuminatingly argue as before that mental, biological, and similar categories must after all be composed of Q-facts, despite first appearances - for otherwise how could they cause their Q-effects, given the completeness thesis that Q-effects always have fully Q-causes? ${ }^{5}$

Here, " $Q$ " is a stand-in for physical facts - meaning the content of $Q$ does not collapse into current or ideal physics. Very importantly, however, " $\mathrm{Q}$ " cannot itself be explicitly defined as physical facts - for then we are defining physicalism by appeal to the notion of "the physical" or "physical facts," and Hempel's Dilemma re-emerges. Furthermore, "Q" captures the kind of reductionism which the physicalist wishes to advance. Montero and Pa-

\footnotetext{
${ }^{3}$ See Melnyk (A Physicalist Manifesto, 12) who adds that if the content of physics is not determinable by us now, then physicalism can be neither supported nor undermined by empirical investigation.

${ }^{4}$ Montero and Papineau, "Naturalism and Physicalism," $187 \mathrm{ff}$. For a very different (and extended) defence against Hempel's Dilemma, see Melnyk, A Physicalist Manifesto, 11-14 and 175-237. Melnyk defends the claim that physicalism can be defined by appeal to current physics.
}

${ }^{5}$ Montero and Papineau, "Naturalism and Physicalism," 187. 
pineau admit that this structural approach allows for a range of detailed theories to count as physicalism. But, they claim, this is not a problem; "physicalism" is a "term of philosophical art that philosophers use in a variety of ways." ${ }^{\prime 6}$ What really matters is that there is causal completeness between Q-causes and Q-effects. The centrality of the causal completeness of " $\mathrm{Q}$ " is especially clear in light of the so-called "causal argument" for physicalism. The argument runs as follows. Substance dualism is problematic because it entails that physical causes are not sufficient for physical effects. Dualism either entails systematic overdetermination (by physical and mental causes at the same time for single effects) or mental causation which is unsystematic and inexplicable in relation to what we know about the physical sciences. While I will not explore these debates in detail here, it is vital to see that (for reasons which will become clear below) idealism can preserve the causal completeness of the " $\mathrm{Q}$ "-realm just as well as traditional physicalism. ${ }^{7}$

To return to the structural definition, this attempt to avoid Hempel's Dilemma fails - in virtue of the fact that its characterisation of physicalism is much too capacious. To see the point, we can plug into the above definition another kind of "reductionism" - one totally alien to physicalism - which would then become "arguably worth calling 'physicalism.'" What might this be?

\section{Jonathan Edwards's Divine Idealism}

Some versions of metaphysical idealism count as physicalism under the structural definition. ${ }^{8}$ I will argue that a particular version of theistic idealism (I will call it simply divine idealism) fits the structural definition of physicalism. The conception of divine idealism I have in mind is the threefold claim that (1) God exists as an immaterial, infinite, and independent mind; (2) all prima facie mind-independent entities - such as oak trees, grand pianos, and up-quarks - are actually ideas in God's mind or collections of ideas in God's mind; and (3) each created mind is actually nothing more than a series of ideas created immediately by God. Indeed, on this version of divine idealism, bodies and created minds possess no existence independent of God's mind whatsoever. A version of this framework was famously advanced by the early American philosopher and theologian Jonathan Edwards. I will briefly lay out Edwards's arguments for these claims - in order to show the texture and coherence of Edwards's metaphysical account.

Edwards claims that bodies (or material objects) are not mind-independent or causally efficacious. This is evidenced by the fact that bodies have

\footnotetext{
'Montero and Papineau, "Naturalism and Physicalism," 188.

${ }^{7}$ For more extensive treatments of the causal argument, see Papineau, "Why Supervenience?" and Montero and Papineau, "Naturalism and Physicalism," $188 \mathrm{ff}$.

${ }^{8}$ Metaphysical idealism has enjoyed a renewal of serious interest of late. See, for example, Cowan and Spiegel's Idealism and Christian Philosophy for several essays on the issue. Of particular interest for our discussion is Taliaferro, "Idealism and the Mind-Body Problem."
} 
no essential property which is truly independent of mind. As Edwards argues:

what idea is that which we call by the name of body? . . 'Tis nothing but color and figure which is the termination of this color, together with some powers such as the power of resisting, and motion, etc., that wholly makes up what we call body. ${ }^{9}$

Edwards took Locke to have shown that color is a mind-dependent property which emerges from the relation between a body and some mind. Furthermore, extension depends either upon color (and is thereby mind-dependent) or upon the solidity of a figure: "If color exists not out of the mind, then nothing belonging to body exists out of the mind but resistance, which is solidity, and the termination of this resistance with its relations, which is figure."10 So solidity or resistance is the best candidate for an extra-mental property which captures the essence of bodies. But even this does not work. For resistance is either an entity on its own, is dependent upon a mind, or is dependent upon color (which is dependent upon a mind). But the first option cannot work-because resistance is merely a relational property and thus cannot subsist mind-independently without color as a subject of inherence. So, resistance (and therefore figure or extension) cannot capture the essence of mind-independent bodies. And, although resistance and color and extension cannot be conceived on their own apart from some other entity, "it is easy to conceive of resistance as a mode of an idea."11 Idealism, then, captures the actual phenomena of bodies better than any theory that attributes mind-independence to bodies.

Edwards's idealism is particularly thoroughgoing in that he suggests that created spirits or minds - and not just bodies - are ultimately to be understood as owing their unity and identity purely to God's mental activity. ${ }^{12}$ This is because, although we perceive ideas from moment to moment, we never perceive a created immaterial substrate or soul which supports our individual ideas. ${ }^{13}$ Edwards writes:

${ }^{9}$ Edwards, Works of Jonathan Edwards, 6:351.

${ }^{10}$ Edwards, Works of Jonathan Edwards, 6:351.

${ }^{11}$ Edwards, Works of Jonathan Edwards, 6:351.

${ }^{12} \mathrm{Edwards}$ writes that "all creatures and all operations of the universe are only the immediate influence of God" (Works of Jonathan Edwards, 13:326; quoted in Reid, "The Metaphysics of Jonathan Edwards and David Hume," 64). For more detailed discussions of Edwards's view of the metaphysics of mind and personal identity - upon which I am drawing heresee Reid, "The Metaphysics of Jonathan Edwards and David Hume," $64 \mathrm{ff}$. and Wainwright, "Jonathan Edwards, God, and 'Particular Minds.'”

${ }^{13}$ As Reid points out, Edwards is similar to David Hume in this negative respect-although the former advocates a positive theistic account of personal identity which Hume would have rejected. 
what we call spirit is nothing but a composition and series of perceptions, or an universe of coexisting and successive perceptions connected by such wonderful methods and laws. ${ }^{14}$

But what precisely does Edwards mean here? Are there many (human) spirits which are somehow responsible for the unity and stability of perceptions or ideas of the external world and of individual minds? Or is my spirit or mind somehow responsible for the unity of my own mind and the external world? No. The human spirit cannot be responsible even for its own unity or identity (much less that of any other spirit or of bodies) because of the causal independence of each particular mind's set of perceptions or ideas from one moment to the next. That is, my existence at a past moment cannot be the true cause of my existence at the present moment because, "no cause can produce effects in a time and place in which itself is not. 'Tis plain, nothing can exert itself, or operate, when and where it is not existing." 15 Given that my own past existence or mental experience (and even the past existence of other created things) cannot possibly be causally sufficient for my existence now, God must be the cause of my existence now: "the existence of created substances, in each successive moment, must be the effect of the immediate agency, will, and power of God."16 As a result, "what we call spirit is nothing but a composition and series of perceptions, or an universe of coexisting and successive perceptions connected by wonderful methods and laws." 17 As Wainwright states it, Edwards's view implies that, "a "particular mind" is nothing more than a series of "thoughts" (mental phenomenalism) that are immediately produced by God."18 But how does God bring about the identity or unity of human minds or spirits? The answer is that personal identity is a function of God's "arbitrary constitution" of things. In short, personal identity or unity of the mind (what substance dualists attribute to the substancehood of the mind) is in fact a constitution arising immediately from divine activity. In short, a person's identity is God sovereignly grouping particular perceptions together in a certain kind of way. ${ }^{19}$ By implication, importantly, any "causal power" we naïvely attribute to created

\footnotetext{
${ }^{14}$ Edwards, Works of Jonathan Edwards, 6:398; quoted in Reid, "The Metaphysics of Jonathan Edwards and David Hume," 66.

${ }^{15}$ Edwards, Works of Jonathan Edwards, 3:400.

${ }^{16}$ Edwards, Works of Jonathan Edwards, 3:401.

${ }^{17}$ Edwards, Works of Jonathan Edwards, Vol. 6, 395; quoted in Wainwright, "Jonathan Edwards, God, and 'Particular Minds,'” 202.

${ }^{18}$ Wainwright, "Jonathan Edwards, God, and 'Particular Minds," 202.

${ }^{19}$ Edwards writes that, "created identity or oneness with past existence, in general, depends on the sovereign constitution and law of the Supreme Author and Disposer of the universe" (Works of Jonathan Edwards, 3:397). Edwards argues for this view in part to defend the Christian doctrine of Original Sin: since personal identity is the basis of moral responsibility - and God can cause it to be the case that personal identity obtains between each human person and Adam - there is no insurmountable objection to the claim that each human person can justly be judged for the sin of Adam.
} 
minds is, properly speaking, to be understood as the causal power of the divine Being and His ideas.

\section{The Problem: Divine Idealism as Physicalism}

Now, I take it that divine idealism, claiming as it does that all things are irreducibly mental (albeit mental in a very different way to substance dualism), is not the kind of thing physicalists have in mind when they affirm the truth of physicalism. Accordingly, any definition of physicalism would be flawed which made divine idealism out to be a kind of physicalism. However (and here's the rub), if Montero and Papineau's attempt to define physicalism is correct, then divine idealism turns out to be "worth calling "physicalism.'" For we can think of "God's thoughts" as the relevant "Q" in Papineau and Montero's formula above, and we can produce a structurally identical reduction in divine idealism. I have laid out below Montero and Papineau's approach to defining physicalism, simply replacing " $Q$ " with "God's thoughts" or "God's mental life":

(1) at first sight mental, biological, and similar categories do not seem to be [thoughts in God's mind], but (2) mental, biological, and similar facts nevertheless do have effects among facts [about God's mental life], while at the same time (3) there is good reason to think that [God's mental life] is "causally complete": that is, that the effects [of God's mental life] always have [complete] causes [in God's mental life].... mental, biological, and similar categories must after all be composed of facts [about God's mental life], despite first appearances-for otherwise how could they cause [thoughts in God's mind], given the completeness thesis that [God's thoughts] always have full [causes in God's own mental life]?

This maps onto Edwards's divine idealism extremely well. Divine idealism then turns out to count as "physicalism" on the structural definition. So, the structural definition fails, and we must return to Hempel's Dilemma.

I can see an initial response to my suggestion, however. Why think that there is the relevant causal completeness of divine ideas? Surely the causal completeness of physics is its distinctive feature-making it structurally distinct from idealism? The first answer from the divine idealist perspective is that the regularity of cause and effect suggests that God's ideas constitute a causally complete world - in a perfect structural parallel to the completeness of physical causes in traditional physicalism. Second, Edwards emphasises that the divine ideas are independent of human cognition. Such a claim suggests that my representation or idea of some oak tree or grand piano (when I am in the presence of one of them) merely participates in the divine idea which pre-exists my entering the room with the piano. The beautiful regularity of nature is independent of human cognition, but in no way independent of the divine mental life. Accordingly, divine idealism seems to support a surprising version of the "physicalist" reduction: because divine ideas are causally complete and responsible for all that happens in the world, the human mind does not genuinely contribute causal activity to the world of things as a separate and substantial 
center of causal agency. And thus the idealist can "reduce" human mental life to the mental life of God. Indeed, Edwards seems to make this kind of idealist "reduction." As in physicalism, this version of divine idealism turns out to entail that the human mind, if we are to preserve its causal capacities, is really something other than what we naïvely thought it was: the "effect" of my will to raise my arm is a result of the God's activity-an activity which is characteristically expressed in natural laws. Whereas on traditional definitions of physicalism the apparent causal power of the human mind is actually constituted by the causal powers of "physical" entities, so in idealism the powers of the human mind are in reality to be understood in terms of divine activity. The reduction is structurally identical, so "physicalism" - as structurally defined-picks out both views equally. In order to distinguish physicalism from divine idealism, there would need to be a working definition of the physical (as opposed to the divine ideational). This raises again Hempel's original dilemma.

\section{Consideration of Objections}

\section{Objection 1: Divine Idealism Is Unscientific}

One possible objection to my argument is that physicalism, unlike idealism, postulates entities which are observable and testable by scientific method-such as gravitons, quarks, and magnetic fields. However, it is not clear that this is correct. Divine idealism can (and does) comfortably postulate such entities too-only not as mind-independent entities. More to the point, however, is that Montero and Papineau's structural definition of physicalism is not meant to depend upon the particular postulates of current physics at all-precisely because of the inevitable recurrence of Hempel's Dilemma. So little seems to turn on this objection.

\section{Objection 2: Physicalism Is Not Substantially Different From Idealism}

Another, stronger objection to my argument is that divine idealism is not substantially different from physicalism, since it simply replaces every naturally occurring entity with a divine idea. To put the point differently, one might worry that divine idealism just amounts to the replacement of every naturalistic fact that $p$ with the claim that God has the idea that $p .^{20}$ Reductionism can therefore be called "physicalism" or "divine idealism" from the perspective of the physicalist; it is merely a linguistic trick to suggest, as I have, that divine idealism counts as "physicalism" in a problematic way. There is no substantive metaphysical difference between the two views; accordingly, there is no problem with the structural definition. This objection should not placate the physicalist; for divine idealism does assert at least four claims which (at least many) physicalists would wish to deny.

First, an infinite, immaterial, and eternal mind (that is, God) exists. Physicalism, as I understand it, is generally meant to deny just such a

\footnotetext{
${ }^{20}$ Thanks to an anonymous reviewer for pointing out this objection.
} 
claim. It may be responded here that there are plenty of physicalists who are also theists - so the existence of one immaterial mind need not be a shock to the physicalist system. Put another way, "physicalism" could be defined locally rather than globally with the structural definition: the human mind is reducible to a set of $Q$ facts, although all mentality may not be reducible to a set of $Q$ facts. This does not save the structural definition. For part of divine idealism is the claim that human mental facts (but not divine mental facts) reduce to some other kind of entity. So, this local form of the structural definition is still too capacious in that it counts divine idealism as physicalism. Importantly, this local version of the structural definition counts divine idealism as "physicalism" whether or not facts about the human mind are reducible to facts about the brain (or quarks, electrons, and the like). Of course, the theist who affirms physicalism may choose to define physicalism locally as the claim that "All minds but God are ultimately reducible to physical entities." However, then Hempel's Dilemma simply re-emerges at the local level.

Second, divine idealism should be problematic to the traditional physicalist because every putatively "physical" or "material," mind-independent object just is in fact a (divine) mental entity. Matter or physical stuff is not genuinely fundamental. ${ }^{21}$ Indeed, stipulated as mind-independent entities, matter (or, let's say, quantum fields or strings) do not exist at all. So, the "reduction" which takes place in divine idealism is "upwards" reduction, whereas the reduction in physicalism is "downwards" reduction. If divine idealism is true, we can keep all the entities that physics postulates - but only as ineliminably mental entities. That is something I think the physicalist will not want to accept. Indeed, this is precisely my point in showing the structural symmetry between the physicalist and idealist reductions: the physicalist will want to maintain a metaphysical difference even though the physics is the same and the "reduction" is structurally the same.

Third, many physicalists want to say that physical entities alone have genuine causal efficacy - whereas immaterial substances or human minds lack genuine causal efficacy. However, on divine idealism no brains, bodies, anvils, or quarks have genuine causal efficacy; nor do finite, immaterial minds. Rather, only the one immaterial divine substance has causal efficacy. This is problematic because it undermines one of the main arguments for physicalism: the causal argument or argument from the causal completeness or closure of the physical. As noted above, the divine idealist can embrace a version of the causal-closure argument by attributing all causal efficacy (both human-mental and physical) to the " $Q$ " realm, namely, God's mental life.

\footnotetext{
${ }^{21}$ Ney sees this commitment fundamental a-mentality or non-mentality as historically central to the development of physicalism: "physicalists preserved the earlier disagreement with dualists and idealists who believed in the existence of distinct mental entities not reducible to physical entities" ("Defining Physicalism," 1034).
} 
A fourth and final difference between divine idealism and traditional physicalism is that divine idealism bears no relation to materialism and physicalism as historically conceived. That is, the physicalist tends to view himself as the sophisticated heir to the project of materialism - the Hobbesian claim that all phenomena are reducible to the activities of material bodies. ${ }^{22}$ This picture was "bottom-up" and revisionist. However, if physicalism is compatible with divine idealism, then it is not the view traditional materialists intended-namely, that appeal to mentality could be fully explained by appeal to fundamental material causes. For the idealist, the world is shot through with mentality-though arguably of a quite different sort than we initially thought. Given these four significant dissonances between traditional physicalism and divine idealism, the objection to my argument fails. There are sufficient substantive metaphysical differences between divine idealism and traditional physicalism to unnerve those who wish to define physicalism structurally.

\section{Objection 3: The Core Program of Physicalism Is Preserved in Divine Idealism}

A third objection to my argument is that, as long as the structural definition of physicalism entails the reduction of facts about prima facie (human) mental states to facts about more fundamental physical entities and forces, the physicalist can still hold to the "core program" of physicalism. ${ }^{23} \mathrm{My}$ response is that nothing about the structural definition guarantees that the putatively mental facts are reducible to physical facts-about brains or quarks or what have you. Rather, all the structural definition shows is that putatively (human) mental facts are reducible to some other kind of facts. Nothing about this definition entails that reduction of mind to brain is specifically in view. Furthermore, nothing about divine idealism requires that there be a reduction from mind to brain before the reduction to divine ideas; the divine idealist may claim that human mental states are not reducible to brain states and yet claim mental states are reducible to the " $\mathrm{Q}$ " category-divine ideas. So, the structural definition of physicalism counts divine idealism as "physicalist" without necessarily preserving the "core project" of reducing mind to brain (or mind to quarks, electrons, etc.).

\section{Objection 4: The "No Fundamental Mentality" Constraint Can Save the Structural Definition}

Another important objection is that divine idealism does not constitute a real reduction of mental facts to other kinds of facts - but only to divine mental facts. It therefore does not really meet the structural definition. Put another way, the structural definition of physicalism (in order to avoid a

\footnotetext{
${ }^{22}$ Wilson claims that, "materialism has been rendered a has-been. Its foundationalist spirit has survived in physicalism, however, reflecting ... a move from an a priori to an a posteriori characterization of the entities supposed to serve as the ontological basis for all else" (Wilson, "On Characterizing the Physical," 62). For a brief overview of this historical project, see Ney, "Defining Physicalism," $1033 \mathrm{ff}$.

${ }^{23}$ Thanks to an anonymous referee for pointing out this objection.
} 
critique like my own) can add the constraint that there is No Fundamental Mentality (NFM) in the " $Q$ " facts - the realm to which all human mental facts are reducible. ${ }^{24}$

I will take these versions of the objection in turn. First, as noted above, divine idealism is radically revisionist in a way which meets the demands of structural physicalism. The substance dualist takes his thoughts to inhere in a unique, finite substance (as one among many finite substances), to have causal powers, and to be uncaused (or at least not immediately caused) by physical facts or divine ideas. On each of these points, divine idealism concurs with physicalism in claiming non-substantiality, causal inadequacy, and "reduction" to another realm - the divine ideational. It is unclear why the reduction of human minds to divine ideas does not count as the proper kind of "reduction." Second, if one wishes to add to the structural definition of physicalism the constraint that there is no fundamental mentality, then we should ask how that stipulation is to be understood - a question which raises another dilemma. On the one hand, we may understand the stipulation as the claim that whatever the putatively human-mental facts are reducible to, such facts cannot themselves be mental in any way. But from the perspective of the divine idealist, physical facts may be (indeed are) reducible to divine ideas. ${ }^{25}$ But I take it that the physicalist wants to say that such a further reduction is inadmissible. So, adding such a stipulation (to rule out a view which reduces all human minds to "physical entities" and then physical entities to divine ideas) makes NFM physicalism look much more like a mere commitment than an inductive hypothesis - as it is usually presumed to be by physicalists. The physicalist might respond here that physicalism is inductively and scientifically motivated, rather than a mere commitment. However, structural physicalism cannot rule out the further "reduction" of physical states to divine ideas on the basis of scientific investigation alone. The NFM constraint therefore is not motivated directly by induction or brain science-for the simple reason that the reduction of human mental states to physical (or brain) states is compatible with a form of divine idealism (under which brain states or physical states are actually ideas in God's mind). On such a version of divine idealism, the reduction of the human mind to the brain is accepted without implying NFM. On the other hand, one might understand the NFM stipulation as the claim that (being a reduction to the a-mental or non-mental) the reduction to " $\mathrm{Q}$ " facts must be ultimately to physical or material facts; but that of course raises Hempel's Dilemma all over again.

\footnotetext{
${ }^{24}$ The No Fundamental Mentality constraint is laid out in Wilson, "On Characterizing the Physical," 69ff.

${ }^{25}$ Edwards writes that "the human body and the human brain exist only mentally, in the same sense that other things do" (Works of Jonathan Edwards, 6:353).
} 


\section{Objection 5: The Claim Is Too Modest}

A final objection to my argument is that my aim here has been quite modest, and this is true. But I would respond in two ways. First, it seems to me philosophically significant that physicalism continues to retreat before attempts to define it. If I am right that the structural definition fails, then one avenue of establishing the definition (namely, the structural) is unlikely to succeed. Second, it is also highly significant-quite apart from the details of Montero and Papineau's structural definition-that some kinds of divine idealism will meet the requirement of the causal completeness argument against substance dualism. That is, if we accept the causal completeness argument, then traditional physicalism is not the only game in town; divine idealism can resolve some of the same issues in very different ways.

\section{Conclusion}

I have by no means attempted to argue here that divine idealism is true. However, my argument here does not in any way depend upon the truth of divine idealism; rather, I merely wish to point out two significant facts about Montero and Papineau's proposed definition of physicalism. First, it has a parallel structure with the historic position of divine idealism in the thought of Jonathan Edwards. Second, the structural definition counts such divine idealism as physicalism - thus undermining the structural approach to defining physicalism. A new dilemma then emerges: either physicalism is not well-defined structurally (and we seem to be back to Hempel's Dilemma) or divine idealism is a kind of physicalism. I suspect the latter will not be a welcome prospect for the physicalist.

\section{King's College London}

\section{References}

Berkeley, George. 1982. A Treatise Concerning the Principles of Human Knowledge (Hackett).

Cowan, Steven, and James S. Spiegel. 2017. Idealism and Christian Philosophy (Bloomsbury).

Crane, Tim, and D. H. Mellor. 1990. "There is No Question of Physicalism." Mind 99, no. 394: 185-206. https://doi.org/10.1093/mind/XCIX.394.185

Edwards, Jonathan. 1957. Works of Jonathan Edwards (Yale University Press).

Hempel, C. G. 1980. "Comments on Goodman's Ways of Worldmaking." Synthese 45: 193-199. https://doi.org/10.1007/BF00413558

Melnyk, Andrew. 2003. A Physicalist Manifesto (Cambridge University Press).

Montero, Barbara Gail, and David Papineau. 2016. "Naturalism and Physicalism." In The Blackwell Companion to Naturalism, edited by Kelly James Clark (Blackwell), 182-195. https://doi.org/10.1002/9781118657775.ch13 
Ney, Alyssa. 2008. “Defining Physicalism." Philosophy Compass 3, no. 5: 1033-1048. https://doi.org/10.1111/j.1747-9991.2008.00163.x

Papineau, David. 1990. “Why Supervenience?" Analysis 50: 66-71. https://doi.org/10.2307/3328848

Reid, Jasper. 2006. "The Metaphysics of Jonathan Edwards and David Hume." Hume Studies 32, no. 1: 53-82. https://doi.org/10.1353/hms.2011.0220

Taliaferro, Charles. 2017. "Idealism and the Mind-Body Problem." In Idealism and Christian Philosophy, ed. Steven Cowan and James S. Spiegel (Bloomsbury), 91-106.

Wainwright, William. 1982. "Jonathan Edwards, Atoms, and Immaterialism." Idealistic Studies 12, no. 1: 79-89. https://doi.org/10.5840/idstudies19821213

Wainwright, William. 2010. "Jonathan Edwards, God, and 'Particular Minds.'” International Journal for Philosophy of Religion 68: 201-213.

https://doi.org/10.1007/s11153-010-9259-0

Wainwright, William. 2016. "Jonathan Edwards." In The Stanford Encyclopedia of Philosophy, edited by Edward N. Zalta. https://plato.stanford.edu/archives/ win2016/entries/edwards/.

Wilson, Jessica. 2006. “On Characterizing the Physical." Philosophical Studies 131, no. 1: 61-99. https://doi.org/10.1007/s11098-006-5984-8 